\title{
COVID-19, a double-edged sword for the environment: a review on the impacts of COVID-19 on the environment
}

\author{
Hossein D. Atoufi ${ }^{1}$ - David J. Lampert ${ }^{1}$ (D) $\cdot$ Mika Sillanpää ${ }^{2,3}$ \\ Received: 20 April 2021 / Accepted: 11 September 2021 / Published online: 23 September 2021 \\ (C) The Author(s), under exclusive licence to Springer-Verlag GmbH Germany, part of Springer Nature 2021
}

\begin{abstract}
This review paper discusses the most relevant impacts of the COVID-19 pandemic on the environment. Severe acute respiratory syndrome coronavirus 2 (SARS-CoV-2) originated in Wuhan, China, in December 2019. The disease has infected 70 million people and caused the death of 1.58 million people since the US Food and Drug Administration issued an Emergency Use Authorization to develop a vaccine to prevent COVID-19 on December 11, 2020. COVID-19 is a global crisis that has impacted everything directly connected with human beings, including the environment. This review discusses the impacts of COVID-19 on the environment during the pandemic and post-COVID-19 era. During the first months of the COVID pandemic, global coal, oil, gas, and electricity demands declined by $8 \%, 5 \%, 2 \%$, and $20 \%$, respectively, relative to 2019. Stay-at-home orders in countries increased the concentrations of particles in indoor environments while decreasing the concentrations of $\mathrm{PM}_{2.5}$ and $\mathrm{NO}_{\mathrm{X}}$ in outdoor environments. Remotely working in response to the COVID-19 pandemic increased the carbon, water, and land footprints of Internet usage. Microplastics are released into our environment from the mishandling and mismanagement of personal protective equipment that endanger our water, soils, and sediments. Since the COVID-19 vaccine cannot be stored for a long time and spoils rapidly, more awareness of the massive waste of unused doses is needed. So COVID-19 is a doubleedged sword for the environment.
\end{abstract}

Keywords COVID-19 - Environment - Indoor air pollution · Water consumption · Microplastics · Climate change Post-COVID $\cdot$ Medical waste

\section{Introduction}

The World Health Organization (WHO) declared a global pandemic of coronavirus disease 2019 (COVID-19), the

Responsible Editor: Lotfi Aleya

David J. Lampert

dlampert1@iit.edu

Hossein D. Atoufi

atoufi@iit.edu

Mika Sillanpää

mika.sillanpaa@tdtu.edu.vn

1 Department of Civil, Architectural, and Environmental Engineering, Illinois Institute of Technology, Chicago, IL, USA

2 Environmental Engineering and Management Research Group, Ton Duc Thang University, Ho Chi Minh City, Vietnam

3 Faculty of Environment and Labour Safety, Ton Duc Thang University, Ho Chi Minh City, Vietnam disease associated with the severe acute respiratory syndrome coronavirus 2 (SARS-CoV-2). This virus originated in Wuhan, Hubei province, China, and it has infected 16.26 million people and caused the death of 0.59 million people globally by March 11, 2020. Nine months later, the US Food and Drug Administration issued the first Emergency Use Authorization for a vaccine to prevent COVID-19 while the numbers escalated to around 70 million and 1.58 million people, respectively (Geneva: World Health Organization 2020). After the WHO's statement, most countries around the world initiated the pandemic lockdown. In the USA, California's state was the precursor that issued the stay-at-home order, and it went into effect on March 19; and by the end of the first week of April, 46 states across the USA had been issued the order statewide or for parts of the state. Besides the stay-athome order, as of April 03, the US Centers for Disease Control and Prevention (CDC) recommended that the public wear masks. Masks or face clothes work as a barrier to prevent the spread of the virus and prevent respiratory droplets from reaching others (CDC 2020). The other most common 
methods to prevent the spread of COVID-19 are good respiratory hygiene, hand washing, hand sanitization using alcohol-based rubs, and social distancing (Thapa et al. 2020; Agusi et al. 2020; Kulkarni et al. 2020; Burnett and Sergi 2020).

Most of the research about COVID-19 has focused on human health and medical aspects, but COVID-19 has indirectly impacted the economy, energy use, and $\mathrm{CO}_{2}$ emissions worldwide. For example, in the middle of April 2020, countries that were entirely locked down experienced a $25 \%$ reduction in energy demand (IEA 2020), while countries that were partially locked down experienced an $18 \%$ reduction in energy demand. Based on the collected data of more than 30 countries, representing approximately $60 \%$ of global energy demand, until April 2020, it is evident that demand depressions are dependent on the duration and severity of lockdowns (IEA 2020). During the first quarter of 2020 , global coal, oil, gas, and electricity demands declined by $8 \%, 5 \%, 2 \%$, and $20 \%$, respectively, compared with the first quarter of 2019. These trends resulted in a drop of almost $8 \%$ in $\mathrm{CO}_{2}$ emissions, reaching the lowest level since 2010 . The reduction is approximately six times greater than the drop of 400 million tons of $\mathrm{CO}_{2}$ recorded in 2009 after the global financial crisis (Koca and Genç 2020). On the other hand, renewable energy demand experienced growth during this outbreak (IEA 2020).

Stay-at-home orders have significantly increased remote work, which has led to fewer flights, travel, and face-to-face meetings. In addition, teleconferencing and virtual meetings have become more prevalent, which has created various new environmental effects. For example, if working remotely and using the internet continues through the end of 2021, the global carbon footprint of the Internet usage, the associated water footprint, and the land footprint related to that data use will increase by 34.3 million tons, 800 million $\mathrm{m}^{3}$, and $1200 \mathrm{~km}^{2}$, respectively (Obringer et al. 2021).

So far, COVID-19 has acted as a double-edged sword for the environment: it has helped the environment by reducing air pollution, greenhouse gas emissions, noise pollution, and human exposure to the environment, but it has harmed ecosystems through increasing solid waste microplastics (MPs) generation. The findings summarized in this review can serve as guidelines to improve environmental outcomes for future pandemics. This double-sided issue needs investigation now to highlight the underlying reasons for positive and negative environmental outcomes. While several papers recently analyzed the positive relationships between the environment and COVID-19 (Eroğlu 2020; Chakraborty and Maity 2020; Gautam and Hens 2020; Saadat et al. 2020; Aydın et al. 2020; Lokhandwala and Gautam 2020; Shakil et al. 2020; SanJuan-Reyes et al. 2021; Mousazadeh et al. 2021), there have been no efforts to summarize both the positive and negative environmental effects comprehensively. This study summarizes all the positive and negative environmental impacts of the response to COVID-19, including indoor and outdoor air, water, and waste both during the pandemic and in the postCOVID-19 era.

\section{COVID-19 and air nexus}

\section{Indoor air quality}

Responses to the COVID pandemic, including lockdown policies and remote work and education, have increased the relevance of exposure to indoor air pollutants for human health. Household cleaning and personal care products, kitchens, laser printers, combustion from fireplaces and smoking, and wall insulation produce indoor air pollutants. The COVID lockdown policies have increased the importance of these sources relative to the pre-COVID period (He and Han 2020; Nwanaji-Enwerem et al. 2020).

A study of an open-kitchen restaurant found that particulate matter (PM) emissions may exceed the US Environmental Protection Agency (EPA) standard. The concentrations of $\mathrm{PM}$ having diameters less than $10 \mu \mathrm{m}\left(\mathrm{PM}_{10}\right)$ and diameters less than $2.5 \mu \mathrm{m}\left(\mathrm{PM}_{2.5}\right)$ were approximately $548.16 \mu \mathrm{g} / \mathrm{m}^{3}$ and $113.14 \mu \mathrm{g} / \mathrm{m}^{3}$ in a week, respectively, while the EPA limits are $35 \mu \mathrm{g} / \mathrm{m}^{3}$ for $\mathrm{PM}_{2.5}$ and $150 \mu \mathrm{g} / \mathrm{m}^{3}$ for $\mathrm{PM}_{10}$ over $24 \mathrm{~h}$ (Chang et al. 2021). Exposure to high levels of PM could lead to respiratory health problems and increase the susceptibility of exposed populations to respiratory diseases like COVID-19, such as asthma, chronic obstructive pulmonary disease, pneumonia, and lung cancer (Shi et al. 2021; Chen et al. 2021; Wang et al. 2021b; Bera et al. 2021; Yu et al. 2021). Due to more activities in the home during a lockdown, small particles generated in the kitchen can be a potential source of pollution (Wimalasena et al. 2021; Zhang et al. 2021a, b; Xiang et al. 2021; Du et al. 2021; Huang et al. 2021).

A study in Seville, Spain, compared the indoor air conditions of two classrooms of a pre-school at two different time points: January 2020 and January 2021. The results showed that the concentrations of $\mathrm{CO}_{2}$ decreased around $36 \%$ on average due to the COVID pandemic. Furthermore, this study showed that using hybrid ventilation during the pandemic resulted in a decrease of $300 \mathrm{ppm}$ in $\mathrm{CO}_{2}$ weekly average concentrations and a reduction of $400 \mathrm{ppm}$ with natural ventilation during all school hours (Alonso et al. 2021).

Researchers compared indoor air quality during and preceding the lockdown in Madrid, Spain, including concentrations of total volatile organic compounds (TVOC), $\mathrm{PM}_{2.5}$, and $\mathrm{CO}_{2}$. During the lockdown, indoor pollution levels increased because the ventilation was inadequate, and cleaning products and disinfectants were used more intensively. The mean daily $\mathrm{PM}_{2.5}$ concentration increased by $12 \%$, and the mean TVOC increased by 37 to 559\% (Domínguez-Amarillo et al. 2020). 
The high levels of TVOC were the result of using cleaning and disinfection products during the COVID-19.

As shown in Fig. 1, people are most interested in using printers during the COVID-19 pandemic. This data given by Google Trends shows that the search interest over time to look for a printer has increased over time after March 2020 (Google 2020). Laser printers emit electrostatically charged fine particles (Tsai et al. 2017; Shin et al. 2019; He and Han 2020; Wang et al. 2021a), which have long residence times in homes due to limited mixing. Emitted particles carry electrostatic charges on their surfaces that are sinks for airborne pathogens like SARS-CoV-2. In addition, charged particles deposit on human lungs more efficiently than neutral particles (He and Han 2020). Therefore, viral exposure risks may be magnified in built environments where printing occurs.

It is possible to reduce the health risks associated with printers by following several steps that include operating printers in well-ventilated areas far away from bedrooms and living rooms, maintaining distance during the printing process to the extent possible, and converting hard copies into digital forms and going paperless. These actions can minimize the exposure risks to printer particles (Zhang et al. 2019; He and Han 2020).

Since cleaners and disinfectants have been used extensively to neutralize COVID-contaminated surfaces, there is increased concern that these products will be misused and over-exposed. Calls to the American Association of Poison Control Centers (AAPCC) regarding exposures to cleaners and disinfectants increased $16 \%$ and $20 \%$ in the first quarter of 2020 compared with the first quarter of 2018 and 2019 , respectively (Chang et al. 2020). Thus, responses to the pandemic thus increased volatile organic compounds, formaldehyde, and other pollutants indoors (Rastogi et al. 2020).

\section{Outdoor air quality}

Declining economic and social activities during the first 5 months of 2020 associated with the COVID-19 pandemic positively affected environmental quality by decreasing the demand for transportation, which reduced concentrations of $\mathrm{PM}_{2.5}$ in eight highly populated US cities (Pata 2020). There is evidence that measured air pollution has declined across the USA during the COVID-19 pandemic, for example, a 4.8-ppb reduction in $\mathrm{NO}_{2}$ concentrations (25.5\%). This decrease was more pronounced in urban counties $(26.0 \%)$ compared to rural ones (16.5\%) (Berman and Ebisu 2020).

The central pollution control board (CPCB) of India examined the air quality index (AQI) before and after the lockdown period (April 2020) using onsite real-time monitoring in Ghaziabad, which is one of the most polluted cities in India. $\mathrm{PM}_{2.5}$ and $\mathrm{NO}_{2}$ were reduced by $46 \%$ and $34 \%$ compared to 2019, respectively. Weekly AQI monitoring in Delhi showed an $82 \%$ decrease, from 301 to 53, between January 14 and April 14, 2020 (Lokhandwala and Gautam 2020).

Another study (Singh and Chauhan 2020) found that the average $\mathrm{PM}_{2.5}$ and AQI decreased significantly during the first isolation period in India across the country. The $\mathrm{PM}_{2.5}$ and AQI in New Delhi, Kolkata, Mumbai, and Hyderabad were approximately reduced by $45,35,27$, and $20 \%$ and $32,22,16$, and $18 \%$ in March 2020 compared to March 2019. Air quality data from 34 monitoring stations in megacity Delhi showed a $60 \%$ and $39 \%$ reduction of $\mathrm{PM}_{10}$ and $\mathrm{PM}_{2.5}$ relative to March
Fig. 1 Global searches for the word "printer" on Google since 2016

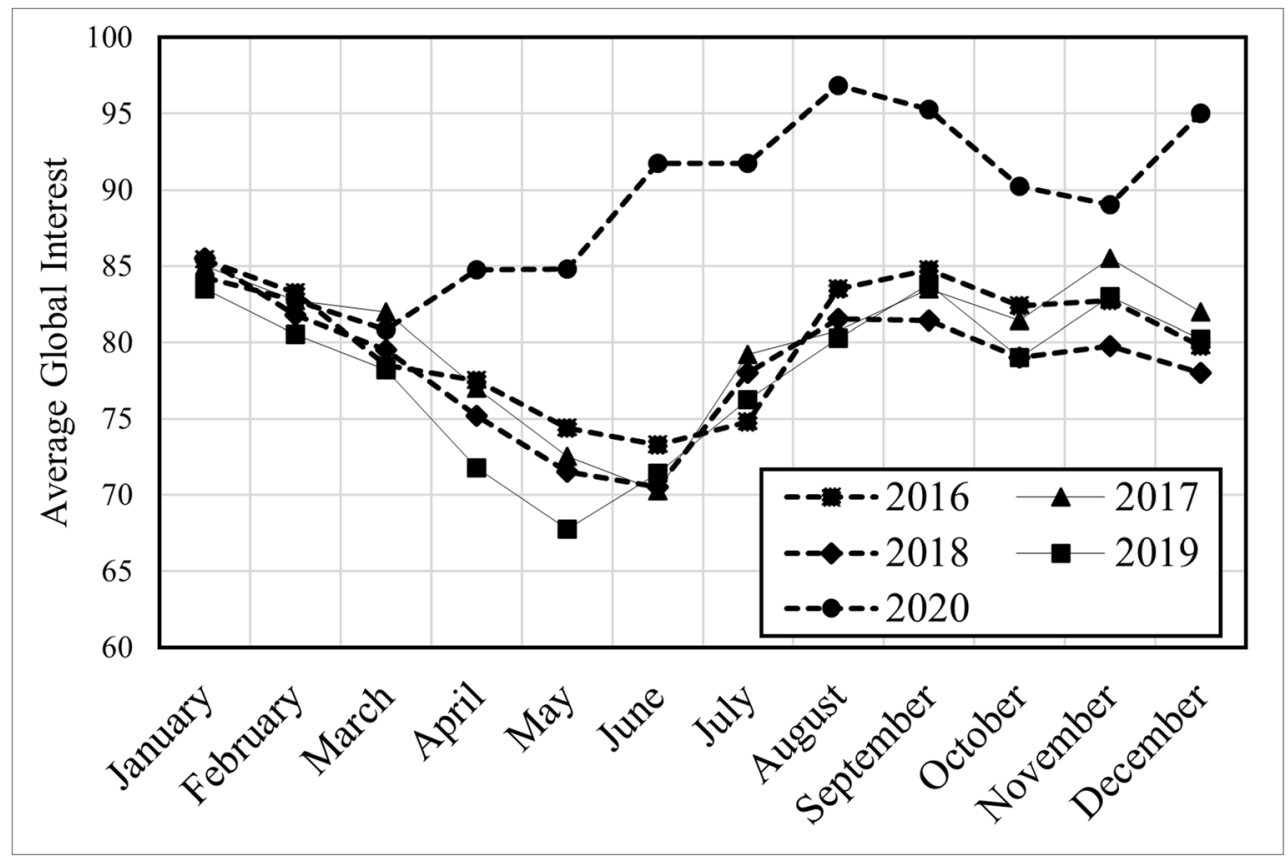


and April 2019. Concentrations of NO2 and CO decreased by $53 \%$ and $30 \%$ during the first isolation period, respectively. Air quality improved by 40 to $50 \% 4$ days after commencing lockdown. The AQI decreased by about $43 \%$ during the 21 day isolation period relative to the first 3 weeks of March 2020 (Mahato et al. 2020). Levels of $\mathrm{PM}_{2.5}, \mathrm{PM}_{10}, \mathrm{NO}_{2}$, and $\mathrm{CO}$ were reduced by $45.45 \%, 35.56 \%, 20.41 \%$, and $17.33 \%$, respectively, in South Korea in 2020 compared with 2019 (Ju et al. 2021).

Lockdowns started earlier in China than other places since it was the first country to experience COVID-19. As a result, air pollution data from January 1 through March 21, 2020, for 44 cities in northern China showed an average AQI decrease of 7.80\%, with $\mathrm{PM}_{2.5}, \mathrm{PM}_{10}, \mathrm{NO}_{2}$, and $\mathrm{CO}$ and $\mathrm{SO}_{2}$ decreases of $5.93 \%, 13.66 \%, 24.67 \%, 4.58 \%$, and $6.76 \%$ respectively (Bao and Zhang 2020). In addition, other studies showed that lockdown initiation reduced $\mathrm{PM}_{2.5}$ by around $30 \%$ in the second quarter of 2020 within China (Giani et al. 2020; Wang et al. 2020; Chu et al. 2021).

Italy, the first European country affected severely by the COVID-19 outbreak, imposed a lockdown on March 09, 2020. As a result, $\mathrm{PM}_{2.5}, \mathrm{PM}_{10}, \mathrm{NO}_{2}, \mathrm{NO}_{\mathrm{x}}, \mathrm{CO}, \mathrm{SO}_{2}$, and benzene levels were reduced by $47.4 \%, 48 \%, 61.4 \%, 74.4 \%$, $57.6 \%, 25.4 \%$, and $69 \%$, respectively, in Milan between a 2week period in February and March 2020 (Collivignarelli et al. 2020).

Finally, the NASA Goddard Earth Observing System (GEOS) atmospheric composition model was used to compare the expected regular atmospheric concentration patterns under pre-COVID-19 assumptions with observations during the pandemic. The results revealed a significant decrease in the level of pollutions. For example, the observed $\mathrm{NO}_{2}$ concentrations for Wuhan, Madrid, and New York were $60 \%, 60 \%$, and $45 \%$ less than forecasted by the GOES model. On average, since February, the response to the pandemic has decreased the levels of global nitrogen dioxide by $20 \%$ (Gray 2020).

\section{COVID-19 and water and wastewater nexus}

One of the first concerns during the COVID-19 pandemic was transmission of the virus through drinking water distribution systems. Regulations require water treatment plants to apply disinfectants such as ozone, chlorine, and ultraviolet light (UV) before delivering water to the distribution system. These disinfection steps kill pathogens in water, much like cleaning activities including hand sanitation and food containers and packaging disinfect pathogens on surfaces. Wastewater treatment plants received more attention during the pandemic, since the spread of SARS-CoV-2 through excrement has been observed in Massachusetts, USA; Southeast Queensland, Australia; Milan, Italy; Valencia, Spain; Amsterdam, Netherland; and Yamanashi Prefecture, Japan
(Lodder and Husman 2020; Medema et al. 2020; Ahmed et al. 2020; Wu et al. 2020; Randazzo et al. 2020; Haramoto et al. 2020; Rimoldi et al. 2020). In these cases, the viral footprint was detected in wastewater collection systems; however, areas with inadequate sanitation treatment facilities need more attention to prevent infected wastewater discharge to the environment.

Beyond water and wastewater networks, rivers, and natural streams may be a potential place to find the SARS-CoV-2. Several studies have been conducted to check the waterways and natural streams (Medema et al. 2020; Guerrero-Latorre et al. 2020; Rimoldi et al. 2020; Tanhaei et al. 2021). Most of this literature did not show any SARS-CoV-2 in river samples, but the study of urban rivers of Quito, Ecuador, was the first study to quantify the presence of the virus in river water (Haramoto et al. 2020; Guerrero-Latorre et al. 2020; Rimoldi et al. 2020). The main reason for the high level of SARS-CoV2 detected in Quito's urban streams seems to be insufficient wastewater disinfection (Guerrero-Latorre et al. 2020).

Direct and indirect use of water substantially changed during the response to the COVID-19 pandemic. Industrial water use decreased as non-essential production was halted, but residential water use increased due to cleaning and disinfection demands. Electricity demand also dropped, which decreased indirect water use required for cooling during power generation. In 2015, electric power generation was responsible for $41 \%, 34 \%$, and $48 \%$ of total water, total freshwater, and fresh surface-water withdrawals in the USA (Dieter et al. 2018). In Italy, the most affected European country by COVID-19, electricity demand decreased by $18 \%$ the week after the lockdown (Cicala 2020). Moreover, electricity generation in Europe decreased by $34 \%$ from lockdown until mid of April. This reduction reduced the water footprint in five European countries (Italy, Spain, Germany, France, and Switzerland) to around $37.5 \%$.

In Joinville, Brazil, water consumption data were remotely collected for different sectors, including commercial, industrial, public, and residential buildings, from the 21st of February to the 12th of April 2020. Water consumption before March 18 increased in the residential sector but decreased in the other sectors. Figure 2 shows water consumption in the four different sectors and compares the results before and after March 18, 2020. Among the non-residential buildings (hotels $(n=5)$, shopping centers $(n=3)$, restaurants $(n=4)$, grocery stores $(n=6)$, education facilities $(n=24)$, and hospitals $((n=8))$, hotels had the most significant decrease by $86 \%$, and hospitals had the lowest reduction by $25 \%$ (Kalbusch et al. 2020).

\section{COVID-19 and microplastics}

During the COVID-19 pandemic, the usage of personal protective equipment (PPE), including hairnet, goggles, gowns, 
Fig. 2 Water consumption for each sector in Joinville, Southern Brazil

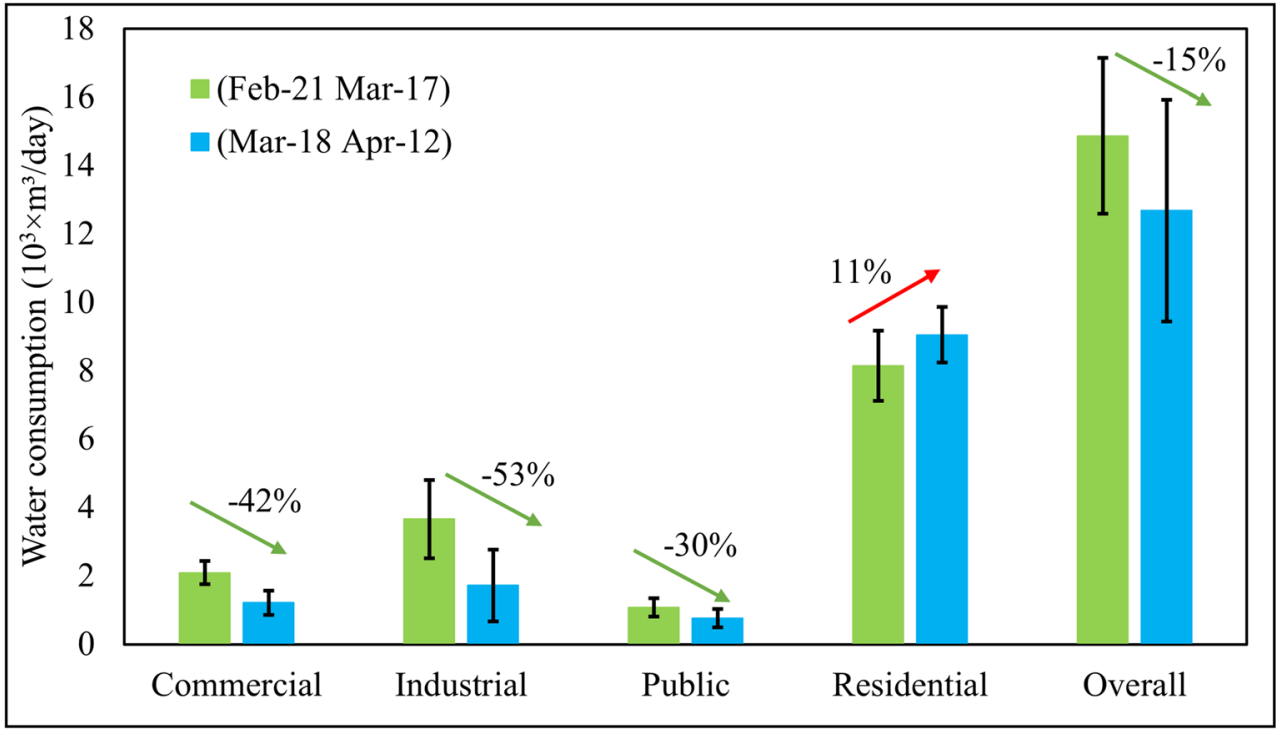

gloves, and face masks, increased dramatically. PPE use is essential to prevent infection, particularly for frontline healthcare workers; however, it increases MPs release. According to the WHO, 89, 76, and 1.6 million medical masks, examination gloves, and goggles are needed, respectively, for healthcare workers monthly during the pandemic (The World Health Organization 2020). For the world population ( 7.8 billion people), approximately 129 billion face masks and 65 billion gloves are needed monthly. Since most PPE is fabricated with plastic polymers, PPE usage presents considerable environmental considerations (Prata et al. 2020).

MPs enter the environment primarily through poor solid waste management. Polymeric materials such as polypropylene, polystyrene, polycarbonate, polyethylene, polyester, or polyethylene terephthalate all generate MPs (Pandey 2020; Prata et al. 2020). Most surgical face masks consist of three layers, including the outer layer, middle layer, and inner layer, made of nonwoven fabric, melt-blown cloth, and soft fibers. The leading layer of single-use masks is the melt-blown cloth, which works as a barrier to germs and bacteria. This main filtering layer is produced by the conventional fabrication of micro- and nanofibers (Fadare and Okoffo 2020). Thus, mismanagement of PPE, such as surgical face masks, results in their release into the environment where they break down and release MPs, spread by wind, rivers, streams, and currents (Prata et al. 2020). If just $1 \%$ of all the masks and gloves are disposed of incorrectly each month and assuming a mass of $3.5 \mathrm{~g}$ for masks and $5.5 \mathrm{~g}$ for a pair of gloves, approximately 4.5 kilotons of masks and 3.6 kilotons of gloves have been dispersed into the environment during the pandemic.

In February 2020, a collection of colored face masks was observed in the water near Soko Islands beach, Hong Kong. In May 2020, a collection of face masks was observed along highway and channel drains in Nigeria (Stokes 2020; Fadare and Okoffo 2020). In June 2020, an environmental NGO took out dozens of surgical masks from the Mediterranean seabed around Antibes, France. Various face masks were observed in Bahir Dar city and Lake Tana's coasts in Ethiopia (Aragaw 2020). In Cape Town and Durban, two South African cities, urban street litter, including face masks and gloves was observed curing pandemic more than regular time (Ryan et al. 2020). Coastal areas of the Persian Gulf and the shoreline of the longest natural beach in the world in Bangladesh are other examples of the irresponsible abandonment of PPE during the COVID-19 pandemic (Akhbarizadeh et al. 2021; Rakib et al. 2021). The authors also observed a large mass of tangled face masks and latex gloves along the Lake Michigan frontage in Chicago, IL, and Niagara Fall State Park, Niagara Falls, NY.

Over time, these materials degrade into smaller pieces because of chemical, physical, and biological reactions happening in the environment, and initiation of degradation is mostly due to UV radiation (De-la-Torre and Aragaw 2021; Zhang et al. 2021c; Saliu et al. 2021; Hasan et al. 2021; Patrício Silva et al. 2021). The generated MPs persist in the environment and continue to pose risks to human health and the environment. MPs can endanger the wildlife and ecosystem for long periods of time (Fadare et al. 2021; Shaikh and Shaikh 2021). There is a risk of microplastics leaking into the ecosystems and affecting the survival, growth, reproduction, feeding, health status, and fitness of water inhabitants. By limiting their mobility and ability to feed, microplastics can pose a threat to the survival and reproduction of various aquatic organisms (Wright et al. 2013; Mohsen et al. 2019; Patrício Silva et al. 2021). The larger MPs block light transfer and affect photosynthesis, whereas the smaller ones are adsorbed to surfaces and damage algal cell walls (Wu et al. 2019; Liu et al. 2020; Larue et al. 2021). In addition, to interference with breathing, gill structures, and swimming, MPs can reduce animal food intake and 
utilization rates while increasing their energy expenditure (Castro-Jiménez et al. 2019; Kögel et al. 2020). Since microplastics have a longer half-life than most natural floating marine substrates, they can form unique hydrophobic surfaces called microgels by utilizing dissolved organic matters in the benthic regions of aquatic ecosystems that promote microbial colonization and biofilm formation. These microgels interrupt food networks in benthic ecosystems (Zettler et al. 2013; Shiu et al. 2020; Patrício Silva et al. 2021).

In September 2020, a juvenile female Magellanic penguin was dead on Juquehy Beach, Brazil, due to the presence of an adult size PFF-2 protective mask within her stomach (Gallo Neto et al. 2021). In Songkhla Lake in Thailand, a biomonitoring study reported high levels of microplastics in the guts of fish and shrimps during the COVID-19 pandemic (Pradit et al. 2021).

The world is still in the pandemic, and PPE should continue to be used even after immunization to prevent COVID spread. So, plastic waste collections, including used face masks, gloves, and vaccine waste, should be separated from other solid waste before disposal (Tripathi et al. 2020; Sharma et al. 2020; Kulkarni and Anantharama 2020; Haque et al. 2021; Behera 2021). Since many people may be unwilling to be vaccinated, and since the COVID-19 vaccine cannot be stored for a long time, some doses will be spoiled. Moreover, in developing countries, cold storage is limited, so many doses may go unused. For instance, more than 16,000 doses of Moderna vaccines and more than 1,000 doses of Pfizer vaccines were spoiled in Maine and Michigan and Palm Beach County, respectively (Salcedo 2021; Marzen 2021). Therefore, authorities and government agencies should be aware of the massive waste of vaccines' environmental impact.

\section{Post-COVID and environment}

The COVID-19 pandemic has forced people and organizations to change their behavior, and those behavioral changes are here to stay for the long term. People may have to avoid crowded spaces for a period if a pandemic recurs. This fear will affect travel and commute patterns and may change the format of business and social gatherings. Most businesses, universities, and schools have switched to remote, social life has changed to social media, and shopping has transitioned to online delivery. Social distancing creates a new concern about the configuration of indoor and outdoor spaces. The COVID19 outbreak was a shock to the world's fossil fuel system. In April 2020, the number of flights decreased by $75 \%$ compared to the same month last year, and aviation $\mathrm{CO}_{2}$ emissions declined significantly (Gössling et al. 2021). As a response to COVID-19, 5 years after the Paris Climate Agreement was adopted, global fossil $\mathrm{CO}_{2}$ emissions decreased to 34
$\mathrm{GtCO}_{2}$. There has never been a decrease in global annual emissions of this magnitude, which is around $2.6 \mathrm{GtCO}_{2}(\mathrm{Le}$ Quéré et al. 2021).

Regarding the energy demand reduction for fossil fuels and fewer emissions of $\mathrm{CO}_{2}$ over the past year, large economies, especially developed countries, are now thinking about strategies to transfer from fossil fuels to green energy (Sánchez Nicolás 2020; Le Quéré et al. 2021; Vetter 2021). So, the pandemic has moved governments and policymakers to think about reducing their dependencies on fossil fuels, speeding up their renewable energy policy efforts, and relying more on green and low-carbon energy systems ahead of another global shock (Hosseini 2020; Mohideen et al. 2021). However, the post-COVID era has not been studied well. While the coronavirus disease has confounded the world, researchers have not had enough time to assess its impact on the environment comprehensively. At present, more research is needed on indoor air quality changes, water contamination with microplastics, methods for decontamination before happening a disaster, and solid waste composition changes.

Additionally, researchers should prepare to examine the environment during any future pandemics using available data and mathematical models to estimate potential side effects. COVID-19 impacts on other major air pollutants should also be evaluated in future research. Researchers should also study the effects of global temperature on virus spread, since climate change could exacerbate future outbreaks (Han et al. 2021; Appiah-Otoo and Kursah 2021). Also, if an outbreak occurs, indoor air pollutants should be investigated to identify the major sources of contamination. Future studies might also consider producing and utilizing eco-friendly PPE. Furthermore, there is a need for more education on managing and handling PPE waste to avoid future environmental disasters. Finally, the concentration of MPs needs to be evaluated to determine a method for decontaminating endangered zones. Research on this topic may help prepare the world for unprecedented events and lead to reduced fossil fuel use, $\mathrm{CO}_{2}$ emissions, and plastic use. The pandemic may also speed the global transition to green energy and low-carbon systems.

\section{Conclusions}

The world disruption caused by SARS-CoV-2 contracted the global economy, reduced energy use and $\mathrm{CO}_{2}$ emissions, and caused many impacts on the environment. The pandemic's response put many countries on lockdown and forced citizens to stay at home. This new era has several pros and cons to the environment. The objectives of this study were to summarize the positive and negative environmental impacts of COVID19. A number of these impacts were observed: 
(1) The pandemic decreased energy demand, coal demand, and electricity demand globally.

(2) Government lockdown orders reduced outdoor air contaminant concentrations in the atmosphere; however, indoor pollution levels result from more in-home activities.

(3) The COVID-19 pandemic decreased water usage, primarily due to the decline in electric power generation. Water consumption decreased for industrial use but increased in the residential sector.

(4) Improper disposal of plastic products caused significant damage to the environment. These items degrade to smaller particles known as microplastics, which harm land and water ecosystems. The release of microplastics is perhaps the most critical environmental issue caused by the response to COVID-19.

(5) The waste of unused and spoiled vaccine doses also causes problems to the environment.

However, herein, most of the effects of COVID-19 on the environment have been addressed; still, researchers should study the impacts of this kind of outbreak disease more. So, using public datasets combined with experimental studies and mathematical modeling can better predict the effects of these kinds of shocks on the environment. Hence, future research can contribute to improving societal lifestyles by providing us with valuable suggestions.

\section{Availability of data and materials Not applicable}

Author contributions H. D. A. conducted the literature review, and drafted and finalized the manuscript; D. J. L. contributed to supervising, writing, and editing. M. S. assisted in drafting the manuscript. All authors have read and approved the manuscript.

\section{Declarations}

Ethics approval and consent to participate Not applicable

Consent for publication Not applicable

Competing interests The authors declare no competing interests.

\section{References}

Agusi ER, Ijoma SI, Nnochin CS et al (2020) The COVID-19 pandemic and social distancing in Nigeria: ignorance or defiance. Pan Afr Med J 35:52. https://doi.org/10.11604/pamj.supp.2020.35.2.23649

Ahmed W, Angel N, Edson J, Bibby K, Bivins A, O'Brien JW, Choi PM, Kitajima M, Simpson SL, Li J, Tscharke B, Verhagen R, Smith WJM, Zaugg J, Dierens L, Hugenholtz P, Thomas KV, Mueller JF (2020) First confirmed detection of SARS-CoV-2 in untreated wastewater in Australia: a proof of concept for the wastewater surveillance of COVID-19 in the community. Sci Total Environ 728: 138764. https://doi.org/10.1016/j.scitotenv.2020.138764
Akhbarizadeh R, Dobaradaran S, Nabipour I, Tangestani M, Abedi D, Javanfekr F, Jeddi F, Zendehboodi A (2021) Abandoned Covid-19 personal protective equipment along the Bushehr shores, the Persian Gulf: an emerging source of secondary microplastics in coastlines. Mar Pollut Bull 168:112386. https://doi.org/10.1016/j.marpolbul. 2021.112386

Alonso A, Llanos J, Escandón R, Sendra JJ (2021) Effects of the COVID19 pandemic on indoor air quality and thermal comfort of primary schools in winter in a Mediterranean climate. Sustainability 13: 2699. https://doi.org/10.3390/su13052699

Appiah-Otoo I, Kursah MB (2021) Modelling spatial variations of novel coronavirus disease (COVID-19): evidence from a global perspective. GeoJournal. https://doi.org/10.1007/s10708-021-10427-0

Aragaw TA (2020) Surgical face masks as a potential source for microplastic pollution in the COVID-19 scenario. Mar Pollut Bull 159:111517. https://doi.org/10.1016/j.marpolbul.2020.111517

Aydın S, Nakiyingi BA, Esmen C, Güneysu S, Ejjada M (2020) Environmental impact of coronavirus (COVID-19) from Turkish perceptive. Environ Dev Sustain. 23:7573-7580. https://doi.org/ 10.1007/s10668-020-00933-5

Bao R, Zhang A (2020) Does lockdown reduce air pollution? Evidence from 44 cities in northern China. Sci Total Environ 731:139052. https://doi.org/10.1016/j.scitotenv.2020.139052

Behera BC (2021) Challenges in handling COVID-19 waste and its management mechanism: a review. Environ Nanotechnol Monit Manag 15:100432. https://doi.org/10.1016/j.enmm.2021.100432

Bera B, Bhattacharjee S, Sengupta N, Saha S (2021) PM2.5 concentration prediction during COVID-19 lockdown over Kolkata metropolitan city, India using MLR and ANN models. Environ Chall 4:100155. https://doi.org/10.1016/j.envc.2021.100155

Berman JD, Ebisu K (2020) Changes in U.S. air pollution during the COVID-19 pandemic. Sci Total Environ 739:139864. https://doi. org/10.1016/j.scitotenv.2020.139864

Burnett ML, Sergi CM (2020) Face masks are beneficial regardless of the level of infection in the fight against COVID-19. Disaster Med Public Health Prep 14:1-4. https://doi.org/10.1017/dmp.2020.320

Castro-Jiménez J, González-Fernández D, Fornier M, Schmidt N, Sempéré R (2019) Macro-litter in surface waters from the Rhone River: plastic pollution and loading to the NW Mediterranean Sea. Mar Pollut Bull 146:60-66. https://doi.org/10.1016/j.marpolbul. 2019.05.067

CDC (2020) Coronavirus Disease 2019 (COVID-19). In: Cent. Dis. Control Prev. https://www.cdc.gov/coronavirus/2019-ncov/ prevent-getting-sick/cloth-face-cover-guidance.html. Accessed 3 Dec 2020

Chakraborty I, Maity P (2020) COVID-19 outbreak: migration, effects on society, global environment and prevention. Sci Total Environ 728: 138882. https://doi.org/10.1016/j.scitotenv.2020.138882

Chang A, Schnall AH, Law R et al (2020) Cleaning and disinfectant chemical exposures and temporal associations with COVID-19 National Poison Data System, United States, January 1, 2020 March 31, 2020. Morb Mortal Wkly Rep 69:496-498. https://doi. org/10.15585/mmwr.mm6916e1

Chang H(S), Capuozzo B, Okumus B, Cho M (2021) Why cleaning the invisible in restaurants is important during COVID-19: a case study of indoor air quality of an open-kitchen restaurant. Int J Hosp Manag 94:102854. https://doi.org/10.1016/j.ijhm.2020.102854

Chen T, Chen F, Wang K et al (2021) Acute respiratory response to individual particle exposure (PM1.0, PM2.5 and PM10) in the elderly with and without chronic respiratory diseases. Environ Pollut 271:116329. https://doi.org/10.1016/j.envpol.2020.116329

Chu B, Zhang S, Liu J, Ma Q, He H (2021) Significant concurrent decrease in $\mathrm{PM}_{2.5}$ and $\mathrm{NO}_{2}$ concentrations in China during COVID-19 epidemic. J Environ Sci 99:346-353. https://doi.org/10.1016/j.jes. 2020.06.031 
Cicala S (2020) Is plunging power demand amid coronavirus a sign of things to come? In: EPIC. https://epic.uchicago.edu/insights/isplunging-power-demand-amid-coronavirus-a-sign-of-things-tocome/. Accessed 13 Dec 2020

Collivignarelli MC, Abbà A, Bertanza G, Pedrazzani R, Ricciardi P, Carnevale Miino M (2020) Lockdown for CoViD-2019 in Milan: what are the effects on air quality? Sci Total Environ 732:139280. https://doi.org/10.1016/j.scitotenv.2020.139280

De-la-Torre GE, Aragaw TA (2021) What we need to know about PPE associated with the COVID-19 pandemic in the marine environment. Mar Pollut Bull 163:111879. https://doi.org/10.1016/j. marpolbul.2020.111879

Dieter CA, Maupin MA, Caldwell RR et al (2018) Estimated use of water in the United States in 2015. U.S. Geological Survey, Reston

Domínguez-Amarillo S, Fernández-Agüera J, Cesteros-García S, González-Lezcano RA (2020) Bad air can also kill: residential indoor air quality and pollutant exposure risk during the COVID-19 crisis. Int J Environ Res Public Health 17:7183. https://doi.org/10. 3390/ijerph17197183

Du W, Wang J, Wang Z et al (2021) Influence of COVID-19 lockdown overlapping Chinese Spring Festival on household PM2.5 in rural Chinese homes. Chemosphere 278:130406. https://doi.org/10.1016/ j.chemosphere.2021.130406

Eroğlu H (2020) Effects of Covid-19 outbreak on environment and renewable energy sector. Environ Dev Sustain. 23:4782-4790. https:// doi.org/10.1007/s10668-020-00837-4

Fadare OO, Okoffo ED (2020) Covid-19 face masks: a potential source of microplastic fibers in the environment. Sci Total Environ 737: 140279. https://doi.org/10.1016/j.scitotenv.2020.140279

Fadare OO, Okoffo ED, Olasehinde EF (2021) Microparticles and microplastics contamination in African table salts. Mar Pollut Bull 164:112006. https://doi.org/10.1016/j.marpolbul.2021.112006

Gallo Neto H, Gomes Bantel C, Browning J, Della Fina N, Albuquerque Ballabio T, Teles de Santana F, de Karam e Britto M, Beatriz Barbosa C (2021) Mortality of a juvenile Magellanic penguin (Spheniscus magellanicus, Spheniscidae) associated with the ingestion of a PFF-2 protective mask during the Covid-19 pandemic. Mar Pollut Bull 166:112232. https://doi.org/10.1016/j.marpolbul.2021. 112232

Gautam S, Hens L (2020) COVID-19: impact by and on the environment, health and economy. Environ Dev Sustain 22:4953-4954. https:// doi.org/10.1007/s10668-020-00818-7

Geneva: World Health Organization (2020) WHO Coronavirus (COVID19) Dashboard. https://covid19.who.int/table. Accessed 11 Dec 2020

Giani P, Castruccio S, Anav A, Howard D, Hu W, Crippa P (2020) Shortterm and long-term health impacts of air pollution reductions from COVID-19 lockdowns in China and Europe: a modelling study. Lancet Planet Health 4:e474-e482. https://doi.org/10.1016/S25425196(20)30224-2

Google (2020) Google Trends. https:/trends.google.com/

Gössling S, Humpe A, Fichert F, Creutzig F (2021) COVID-19 and pathways to low-carbon air transport until 2050. Environ Res Lett 16:034063. https://doi.org/10.1088/1748-9326/abe90b

Gray E (2020) Model Shows Extent COVID-related Pollution Levels Deviated from Norm. In: NASA. http://www.nasa.gov/feature/ goddard/2020/nasa-model-reveals-how-much-covid-relatedpollution-levels-deviated-from-the-norm. Accessed 6 Dec 2020

Guerrero-Latorre L, Ballesteros I, Villacrés-Granda I, Granda MG, Freire-Paspuel B, Ríos-Touma B (2020) SARS-CoV-2 in river water: implications in low sanitation countries. Sci Total Environ 743: 140832. https://doi.org/10.1016/j.scitotenv.2020.140832

Han C, Li M, Haihambo N, Babuna P, Liu Q, Zhao X, Jaeger C, Li Y, Yang S (2021) Mechanisms of recurrent outbreak of COVID-19: a model-based study. Nonlinear Dyn. https://doi.org/10.1007/s11071021-06371-w
Haque MS, Uddin S, Sayem SM, Mohib KM (2021) Coronavirus disease 2019 (COVID-19) induced waste scenario: a short overview. J Environ Chem Eng 9:104660. https://doi.org/10.1016/j.jece.2020. 104660

Haramoto E, Malla B, Thakali O, Kitajima M (2020) First environmental surveillance for the presence of SARS-CoV-2 RNA in wastewater and river water in Japan. Sci Total Environ 737:140405. https://doi. org/10.1016/j.scitotenv.2020.140405

Hasan NA, Heal RD, Bashar A, Haque MM (2021) Face masks: protecting the wearer but neglecting the aquatic environment? - a perspective from Bangladesh. Environ Chall 4:100126. https://doi. org/10.1016/j.envc.2021.100126

He S, Han J (2020) Electrostatic fine particles emitted from laser printers as potential vectors for airborne transmission of COVID-19. Environ Chem Lett. 19:17-24. https://doi.org/10.1007/s10311020-01069-8

Hosseini SE (2020) An outlook on the global development of renewable and sustainable energy at the time of COVID-19. Energy Res Soc Sci 68:101633. https://doi.org/10.1016/j.erss.2020.101633

Huang L, Cheng H, Ma S, He R, Gong J, Li G, An T (2021) The exposures and health effects of benzene, toluene and naphthalene for Chinese chefs in multiple cooking styles of kitchens. Environ Int 156:106721. https://doi.org/10.1016/j.envint.2021.106721

IEA (2020) Global Energy Review 2020. In: IEA. https://www.iea.org/ reports/global-energy-review-2020. Accessed 15 Dec 2020

Ju MJ, Oh J, Choi Y-H (2021) Changes in air pollution levels after COVID-19 outbreak in Korea. Sci Total Environ 750:141521. https://doi.org/10.1016/j.scitotenv.2020.141521

Kalbusch A, Henning E, Brikalski MP, Luca FV, Konrath AC (2020) Impact of coronavirus (COVID-19) spread-prevention actions on urban water consumption. Resour Conserv Recycl 163:105098. https://doi.org/10.1016/j.resconrec.2020.105098

Koca K, Genç MS (2020) Effects of 2019 Novel Coronavirus (COVID19) Outbreak on global energy demand and the electricity production with renewables: a comprehensive survey. Sigma J Eng Nat Sci 38:1369-1380

Kögel T, Bjorøy Ø, Toto B, Bienfait AM, Sanden M (2020) Micro- and nanoplastic toxicity on aquatic life: determining factors. Sci Total Environ 709:136050. https://doi.org/10.1016/j.scitotenv.2019. 136050

Kulkarni BN, Anantharama V (2020) Repercussions of COVID-19 pandemic on municipal solid waste management: challenges and opportunities. Sci Total Environ 743:140693. https://doi.org/10.1016/j. scitotenv.2020.140693

Kulkarni T, Sharma P, Pande P, Agrawal R, Rane S, Mahajan A (2020) COVID-19: a review of protective measures. Cancer Res Stat Treat 3:244. https://doi.org/10.4103/CRST.CRST 17220

Larue C, Sarret G, Castillo-Michel H, del Real AEP (2021) A critical review on the impacts of nanoplastics and microplastics on aquatic and terrestrial photosynthetic organisms. Small 17:2005834. https:// doi.org/10.1002/smll.202005834

Le Quéré C, Peters GP, Friedlingstein P et al (2021) Fossil $\mathrm{CO}_{2}$ emissions in the post-COVID-19 era. Nat Clim Change 11:197-199. https:// doi.org/10.1038/s41558-021-01001-0

Liu G, Jiang R, You J, Muir DCG, Zeng EY (2020) Microplastic impacts on microalgae growth: effects of size and humic acid. Environ Sci Technol 54:1782-1789. https://doi.org/10.1021/acs.est.9b06187

Lodder W, Husman AM d R (2020) SARS-CoV-2 in wastewater: potential health risk, but also data source. Lancet Gastroenterol Hepatol 5: 533-534. https://doi.org/10.1016/S2468-1253(20)30087-X

Lokhandwala S, Gautam P (2020) Indirect impact of COVID-19 on environment: a brief study in Indian context. Environ Res 188:109807. https://doi.org/10.1016/j.envres.2020.109807

Mahato S, Pal S, Ghosh KG (2020) Effect of lockdown amid COVID-19 pandemic on air quality of the megacity Delhi, India. Sci Total 
Environ 730:139086. https://doi.org/10.1016/j.scitotenv.2020. 139086

Marzen CG (2021) COVID-19 vaccine distribution: a brief proposal for future pandemics. Social Science Research Network, Rochester

Medema G, Heijnen L, Elsinga G, Italiaander R, Brouwer A (2020) Presence of SARS-coronavirus-2 RNA in sewage and correlation with reported COVID-19 prevalence in the early stage of the epidemic in The Netherlands. Environ Sci Technol Lett 7:511-516. https://doi.org/10.1021/acs.estlett.0c00357

Mohideen MM, Ramakrishna S, Prabu S, Liu Y (2021) Advancing green energy solution with the impetus of COVID-19 pandemic. J Energy Chem 59:688-705. https://doi.org/10.1016/j.jechem.2020.12.005

Mohsen M, Wang Q, Zhang L, Sun L, Lin C, Yang H (2019) Microplastic ingestion by the farmed sea cucumber Apostichopus japonicus in China. Environ Pollut 245:1071-1078. https://doi.org/ 10.1016/j.envpol.2018.11.083

Mousazadeh M, Paital B, Naghdali Z, Mortezania Z, Hashemi M, Karamati Niaragh E, Aghababaei M, Ghorbankhani M, Lichtfouse E, Sillanpää M, Hashim KS, Emamjomeh MM (2021) Positive environmental effects of the coronavirus 2020 episode: a review. Environ Dev Sustain. 23:12738-12760. https://doi.org/10.1007/ s10668-021-01240-3

Nwanaji-Enwerem JC, Allen JG, Beamer PI (2020) Another invisible enemy indoors: COVID-19, human health, the home, and United States indoor air policy. J Expo Sci Environ Epidemiol 30:773-775. https://doi.org/10.1038/s41370-020-0247-x

Obringer R, Rachunok B, Maia-Silva D, Arbabzadeh M, Nateghi R, Madani K (2021) The overlooked environmental footprint of increasing Internet use. Resour Conserv Recycl 167:105389. https:// doi.org/10.1016/j.resconrec.2020.105389

Pandey S (2020) Design and Manufacturing of Personal Protective Equipment (ppe) in Nepal

Pata UK (2020) How is COVID-19 affecting environmental pollution in US cities? Evidence from asymmetric Fourier causality test. Air Qual Atmosphere Health 13:1149-1155. https://doi.org/10.1007/ s11869-020-00877-9

Patrício Silva AL, Prata JC, Mouneyrac C, Barcelò D, Duarte AC, RochaSantos T (2021) Risks of Covid-19 face masks to wildlife: present and future research needs. Sci Total Environ 792:148505. https:// doi.org/10.1016/j.scitotenv.2021.148505

Pradit S, Noppradit P, Goh BP et al (2021) Occurrence of microplastics and trace metals in fish and shrimp from Songkhla lake, Thailand during the COVID-19 pandemic. Appl Ecol Environ Res 19:10851106. https://doi.org/10.15666/aeer/1902 10851106

Prata JC, Silva ALP, Walker TR, Duarte AC, Rocha-Santos T (2020) COVID-19 pandemic repercussions on the use and management of plastics. Environ Sci Technol 54:7760-7765. https://doi.org/10. 1021/acs.est.0c02178

Rakib MRJ, De-la-Torre GE, Pizarro-Ortega CI et al (2021) Personal protective equipment (PPE) pollution driven by the COVID-19 pandemic in Cox's Bazar, the longest natural beach in the world. Mar Pollut Bull 169:112497. https://doi.org/10.1016/j.marpolbul.2021. 112497

Randazzo W, Cuevas-Ferrando E, Sanjuán R, Domingo-Calap P, Sánchez G (2020) Metropolitan wastewater analysis for COVID19 epidemiological surveillance. Int J Hyg Environ Health 230: 113621. https://doi.org/10.1016/j.ijheh.2020.113621

Rastogi P, Sobek ON, Jephson G, Allison J (2020) A data-driven indoor air quality framework for post-COVID-19 workplace re-entry. Arbnco Ltd., Glasgow

Rimoldi SG, Stefani F, Gigantiello A et al (2020) Presence and infectivity of SARS-CoV-2 virus in wastewaters and rivers. Sci Total Environ 744:140911. https://doi.org/10.1016/j.scitotenv.2020.140911

Ryan PG, Maclean K, Weideman EA (2020) The impact of the COVID19 lockdown on urban street litter in South Africa. Environ Process 7:1303-1312. https://doi.org/10.1007/s40710-020-00472-1
Saadat S, Rawtani D, Hussain CM (2020) Environmental perspective of COVID-19. Sci Total Environ 728:138870. https://doi.org/10.1016/ j.scitotenv.2020.138870

Salcedo A (2021) More than 16,000 vaccine doses potentially spoiled in Maine and Michigan by temperature problems. Wash, Post

Saliu F, Veronelli M, Raguso C, Barana D, Galli P, Lasagni M (2021) The release process of microfibers: from surgical face masks into the marine environment. Environ Adv 4:100042. https://doi.org/10. 1016/j.envadv.2021.100042

Sánchez Nicolás E (2020) Germany ready to lead green recovery post coronavirus. In: EUobserver. https://euobserver.com/green-deal/ 148206. Accessed 2 Jul 2021

SanJuan-Reyes S, Gómez-Oliván LM, Islas-Flores H (2021) COVID-19 in the environment. Chemosphere 263:127973. https://doi.org/10. 1016/j.chemosphere.2020.127973

Shaikh IV, Shaikh VAE (2021) A comprehensive review on assessment of plastic debris in aquatic environment and its prevalence in fishes and other aquatic animals in India. Sci Total Environ 779:146421. https://doi.org/10.1016/j.scitotenv.2021.146421

Shakil MH, Munim ZH, Tasnia M, Sarowar S (2020) COVID-19 and the environment: a critical review and research agenda. Sci Total Environ 745:141022. https://doi.org/10.1016/j.scitotenv.2020. 141022

Sharma HB, Vanapalli KR, Cheela VS et al (2020) Challenges, opportunities, and innovations for effective solid waste management during and post COVID-19 pandemic. Resour Conserv Recycl 162: 105052. https://doi.org/10.1016/j.resconrec.2020.105052

Shi W, Liu C, Annesi-Maesano I et al (2021) Ambient $\mathrm{PM}_{2.5}$ and its chemical constituents on lifetime-ever pneumonia in Chinese children: a multi-center study. Environ Int 146:106176. https://doi.org/ 10.1016/j.envint.2020.106176

Shin N, Velmurugan K, Su C, Bauer AK, Tsai CSJ (2019) Assessment of fine particles released during paper printing and shredding processes. Environ Sci Process Impacts 21:1342-1352. https://doi.org/10. 1039/C9EM00015A

Shiu R-F, Vazquez CI, Tsai Y-Y, Torres GV, Chen CS, Santschi PH, Quigg A, Chin WC (2020) Nano-plastics induce aquatic particulate organic matter (microgels) formation. Sci Total Environ 706: 135681. https://doi.org/10.1016/j.scitotenv.2019.135681

Singh RP, Chauhan A (2020) Impact of lockdown on air quality in India during COVID-19 pandemic. Air Qual Atmosphere Health 13:921928. https://doi.org/10.1007/s11869-020-00863-1

Stokes G (2020) No Shortage of Masks at the Beach. In: Oceans Asia. https://oceansasia.org/beach-mask-coronavirus/. Accessed 14 Dec 2020

Tanhaei M, Mohebbi SR, Hosseini SM, Rafieepoor M, Kazemian S, Ghaemi A, Shamloei S, Mirjalali H, Asadzadeh Aghdaei H, Zali MR (2021) The first detection of SARS-CoV-2 RNA in the wastewater of Tehran, Iran. Environ Sci Pollut Res. 28:38629-38636. https://doi.org/10.1007/s11356-021-13393-9

Thapa A, Malla M, Thapa SK (2020) Impact of COVID-19 public health measures on other respiratory illnesses. J Patan Acad Health Sci 7: 62-65. https://doi.org/10.3126/jpahs.v7i1.28865

The World Health Organization (2020) Shortage of personal protective equipment endangering health workers worldwide. https://www. who.int/news/item/03-03-2020-shortage-of-personal-protectiveequipment-endangering-health-workers-worldwide. Accessed 13 Dec 2020

Tripathi A, Tyagi VK, Vivekanand V, Bose P, Suthar S (2020) Challenges, opportunities and progress in solid waste management during COVID-19 pandemic. Case Stud Chem Environ Eng 2: 100060. https://doi.org/10.1016/j.cscee.2020.100060

Tsai CS-J, Shin N, Castano A, Khattak J, Wilkerson AM, Lamport NR (2017) A pilot study on particle emission from printer paper shredders. Aerosol Sci Technol 51:57-68. https://doi.org/10.1080/ 02786826.2016 .1250865 
Vetter D (2021) Covid vs coal: has the pandemic accelerated Europe's green energy transition? In: Forbes. https:/www.forbes.com/sites/ davidrvetter/2021/04/13/covid-vs-coal-did-the-pandemicaccelerate-europes-green-energy-transition/. Accessed 2 Jul 2021

Wang Y, Wen Y, Wang Y, Zhang S, Zhang KM, Zheng H, Xing J, Wu Y, Hao J (2020) Four-month changes in air quality during and after the COVID-19 lockdown in six megacities in China. Environ Sci Technol Lett 7:802-808. https://doi.org/10.1021/acs.estlett.0c00605

Wang H, He C, Modini RL, Wang W, Lu H, Morawska L (2021a) Mixing state of printer generated ultrafine particles: implications for the complexity of indoor aerosols. Atmos Environ 259:118550. https://doi.org/10.1016/j.atmosenv.2021.118550

Wang X, Xu Z, Su H, Ho HC, Song Y, Zheng H, Hossain MZ, Khan MA, Bogale D, Zhang H, Wei J, Cheng J (2021b) Ambient particulate matter $\left(\mathrm{PM}_{1}, \mathrm{PM}_{2.5}, \mathrm{PM}_{10}\right)$ and childhood pneumonia: the smaller particle, the greater short-term impact? Sci Total Environ 772: 145509. https://doi.org/10.1016/j.scitotenv.2021.145509

Wimalasena NN, Chang-Richards A, Wang KI-K, Dirks KN (2021) Housing risk factors associated with respiratory disease: a systematic review. Int J Environ Res Public Health 18:2815. https://doi.org/ 10.3390/ijerph18062815

Wright SL, Thompson RC, Galloway TS (2013) The physical impacts of microplastics on marine organisms: a review. Environ Pollut 178: 483-492. https://doi.org/10.1016/j.envpol.2013.02.031

Wu Y, Guo P, Zhang X, Zhang Y, Xie S, Deng J (2019) Effect of microplastics exposure on the photosynthesis system of freshwater algae. J Hazard Mater 374:219-227. https://doi.org/10.1016/j. jhazmat.2019.04.039

Wu F, Zhang J, Xiao A, et al (2020) SARS-CoV-2 titers in wastewater are higher than expected from clinically confirmed cases. mSystems 5:. https://doi.org/10.1128/mSystems.00614-20

Xiang J, Hao J, Austin E, Shirai J, Seto E (2021) Residential cookingrelated $\mathrm{PM}_{2.5}$ : spatial-temporal variations under various intervention scenarios. Build Environ 201:108002. https://doi.org/10.1016/j. buildenv.2021.108002

Yu P, Xu R, Coelho MSZS, Saldiva PHN, Li S, Zhao Q, Mahal A, Sim M, Abramson MJ, Guo Y (2021) The impacts of long-term exposure to $\mathrm{PM}_{2.5}$ on cancer hospitalizations in Brazil. Environ Int 154: 106671. https://doi.org/10.1016/j.envint.2021.106671

Zettler ER, Mincer TJ, Amaral-Zettler LA (2013) Life in the "Plastisphere": microbial communities on plastic marine debris. Environ Sci Technol 47:7137-7146. https://doi.org/10.1021/ es $401288 \mathrm{x}$

Zhang Q, Pardo M, Rudich Y, Kaplan-Ashiri I, Wong JPS, Davis AY, Black MS, Weber RJ (2019) Chemical composition and toxicity of particles emitted from a consumer-level 3D printer using various materials. Environ Sci Technol 53:12054-12061. https://doi.org/ 10.1021/acs.est.9b04168

Zhang A, Liu Y, Zhao B, Zhang Y, Kan H, Zhao Z, Deng F, Huang C, Zeng X, Sun Y, Qian H, Liu W, Mo J, Sun C, Zheng X (2021a) Indoor $\mathrm{PM}_{2.5}$ concentrations in China: a concise review of the literature published in the past 40 years. Build Environ 198:107898. https://doi.org/10.1016/j.buildenv.2021.107898

Zhang J, Gao J, Wang J, Cao C, Xie M, Zeng L, Lv L (2021b) The performance of different ventilation methods in residential kitchens with different spatial organizations: A literature review. Build Environ 201:107990. https://doi.org/10.1016/j.buildenv.2021. 107990

Zhang K, Hamidian AH, Tubić A, Zhang Y, Fang JKH, Wu C, Lam PKS (2021c) Understanding plastic degradation and microplastic formation in the environment: a review. Environ Pollut 274:116554. https://doi.org/10.1016/j.envpol.2021.116554

Publisher's note Springer Nature remains neutral with regard to jurisdictional claims in published maps and institutional affiliations. 